\title{
Nutritive value of lucerne-leaf proteins
}

\author{
Biological value of lucerne proteins and their supplementary relations \\ to rice proteins measured by balance and rat-growth methods
}

\author{
BY B. K. SUR* \\ Central Food Technological Research Institute, Mysore, India
}

(Received 9 Fanuary 1961-Revised 17 April 1961)

Lucerne (Medicago sativa L.) is essentially a forage crop, but has been eaten to a small extent by human beings (Levy \& Fox, I935; Odendaal, 1954). A cereal mixture containing I $\%$ of dehydrated lucerne was given for 2 years, with considerable success, in the Hospital for Sick Children in Toronto (Brown \& Tisdall, 1933). Recognition of the high nutritive value of lucerne has led a number of workers to suggest its use as an ingredient in human diets (Levy \& Fox, 1935; Marston, Quinlan-Watson \& Dewey, I943; Escudero \& Landabure, r943). Methods of preparing it as a vegetable dish were described by Heupke \& Schöller (1942, 1943). Carotene and protein concentrates were made from lucerne by White, Weil, Naghski, Monica \& William (1948). Anandswamy \& Date (1956) made a lucerne concentrate which was found to be acceptable when included in sugar-coated tablets or in dehydrated soup mixtures.

The rice diet generally consumed in South India is a poor diet deficient in proteins and in certain minerals and vitamins (Aykroyd \& Krishnan, 1937a-c). The fact that lucerne is rich in many of these nutrients, and is also a widely grown crop giving high yields, led Subrahmanyan \& Sur (1949) to explore the possibility of using it as a cheap and nutritious supplement to a poor rice diet. Experiments on successive generations of albino rats showed that desiccated lucerne leaf, when given as a supplement to the poor rice diet at a $10 \%$ level, increased the rate of growth three- or four-fold.

It seemed important to ascertain how far the effect of the lucerne in accelerating growth was due to supplementary relations between rice and lucerne proteins. Few investigations have been done on leaf proteins with rats as experimental animals, compared with the large number concerned with the value of proteins in cereals, pulses and foods of animal origin. It was thought that information on lucerne-leaf proteins obtained by this means would help in planning cheap and well-balanced diets in rice-eating areas.

In the present paper, experiments on the biological value of lucerne-leaf proteins and their supplementary relations to rice proteins are described. Both the ThomasMitchell balance-sheet method and the rat-growth method were used. Whole lucerneleaf powder was given throughout, since the object was to ascertain the value of the

\footnotetext{
* Present address: G.S.V.M. Medical College, Kanpur, India.
} 
whole leaf and not of the extracted protein. The effect of mild autoclaving on the protein efficiency ratio was also investigated, with the idea in mind that lucerne has to be processed to make it palatable and that autoclaving might reproduce in some degree the effects of processing.

\section{EXPERIMENT AL}

\section{Preparation of lucerne-leaf powder}

Lucerne plants, $1 \frac{1}{2}-2 \mathrm{ft}$ in height, were cut before flowering, thoroughly washed and then dried in a current of air at $60^{\circ}$. The dried leaves were separated from the stem, powdered and passed through a 40 -mesh sieve. Fresh lucerne powder was prepared for each experiment. The powder used for the experiments with the balancesheet method contained $33 \%$ crude protein and $27.7 \%$ true protein (insoluble in $5 \%$ trichloroacetic acid). The powder used in the growth tests contained $30.6 \%$ crude protein. Autoclaved lucerne was prepared by wetting lucerne powder with water, autoclaving it in steam at $2 \mathrm{lb}$ pressure for $\frac{1}{2} \mathrm{~h}$, and then drying it in a current of hot air at $60^{\circ}$.

\section{Diet and feeding of animals}

In the balance experiments, the ratio of lucerne protein to rice protein in the experimental diet was set at $2: 3$, this ratio being similar to that adopted in earlier studies on the growth-promoting effect of lucerne supplements added to the poor rice diet (Subrahmanyan \& Sur, 1949). For the growth tests, two diets containing mixed proteins (lucerne protein:rice protein $=I: I$ and $I: 3$ ) were used. The lower proportion of lucerne protein was chosen in this test because earlier experiments had shown that even small additions of lucerne to the poor rice diet have a marked growth-promoting effect (Sur \& Subrahmanyan, 1954).

The composition of the experimental diets is shown in Tables $\mathrm{I}$ and 2. The biological value of lucerne proteins, of a mixture of lucerne and rice proteins, and of rice proteins alone, was determined in succession in that order, at the same level of protein intake, by the Thomas-Mitchell balance-sheet technique, five healthy adult male rats weighing about $\mathrm{I} 50 \mathrm{~g}$ being used. The methods were similar to those described by Swaminathan (I937). The experimental animals were given a nitrogen-free diet in the first and the last periods. Diets containing lucerne proteins, a mixture of rice and lucerne proteins, rice proteins alone, and lucerne proteins alone, were given in the 2nd, $3^{\text {rd }}$ and $4^{\text {th }}$ periods respectively. Each period consisted of 7 days. Between two consecutive periods, there was a rest period of 4 days when the rats were given the stock diet. The first 3 days of each experimental period were considered as a reorientation period and urine and faeces were collected during the last 4 days. Urine was collected in bottles containing $30 \mathrm{ml} 2.5 \%(\mathrm{v} / \mathrm{v})$ sulphuric acid, A.R., and a small amount of toluene. Faeces were washed daily with a few $\mathrm{ml}$ of water to remove any adhering urine, transferred to a $500 \mathrm{ml} \mathrm{Kjeldahl} \mathrm{flask} \mathrm{and} \mathrm{digested.} \mathrm{The} \mathrm{digest} \mathrm{was}$ made up to $250 \mathrm{ml}$ and a portion taken for estimation of nitrogen by the microKjeldahl method. One sample of urine was lost during the experiment and results are given for only five rats. 
For the growth experiments newly weaned rats weighing about $40 \mathrm{~g}$ were distributed into five groups each containing six rats. Only male rats were used, since in growth experiments considerable variation due to sex difference may occur. The rats were fed ad lib. for a period of 6 weeks. The protein efficiency ratio was calculated as gain in weight of experimental animals per $\mathrm{g}$ protein intake (Osborne, Mendel \& Ferry, 1919).

Table I. Percentage composition of diets used for the evaluation of the biological value of proteins by the balance method

\begin{tabular}{|c|c|c|c|c|}
\hline Ingredient & $\begin{array}{c}\text { Nitrogen-free } \\
\text { diet }\end{array}$ & $\begin{array}{l}\text { Lucerne } \\
\text { diet }\end{array}$ & $\begin{array}{l}\text { Lucerne and } \\
\text { rice diet }\end{array}$ & Rice diet \\
\hline Lucerne-leaf flour & - & $16 \cdot 3$ & 6.6 & - \\
\hline Rice & - & - & $45^{\circ} 4$ & $76 \cdot 0$ \\
\hline Coconut oil & $10 \cdot 0$ & $10 \cdot 0$ & $10 \cdot 0$ & $10 \cdot 0$ \\
\hline Cane sugar & $10 \cdot 0$ & 10.0 & $10 \cdot 0$ & $10 \cdot 0$ \\
\hline Salt mixture* & $4 \cdot 0$ & $4 \cdot 0$ & $4 \cdot 0$ & $4 \cdot 0$ \\
\hline Vitaminized starch $\dagger$ & I.O & $1 \cdot 0$ & $I \cdot 0$ & - \\
\hline Starch (maize) & $75^{\circ} \mathrm{o}$ & $58 \cdot 7$ & $23 \cdot 0$ & - \\
\hline Nitrogen & 0.049 & 0.899 & $0.86_{5}$ & 0.858 \\
\hline Protein $(N \times 6.25)$ & $0.3 \mathrm{I}$ & $5 \cdot 62$ & $5 \cdot 4 \mathrm{I}$ & $5 \cdot 36$ \\
\hline Moisture & $9 \cdot 2$ & $8 \cdot 2$ & $8 \cdot 4$ & $8 \cdot 6$ \\
\hline
\end{tabular}

* Osborne \& Mendel (1913).

$\dagger$ I g contained $0.25 \mathrm{mg}$ thiamine hydrochloride, $0.5 \mathrm{mg}$ riboflavin and $0.5 \mathrm{mg}$ nicotinic acid. Equivalent quantities of vitamins were added to rice flour in the rice diet. Each rat received daily one drop of shark-liver oil containing 1500 i.u. vitamin A and roo i.u. vitamin D per g. During the rest periods the rats were fed on a stock diet containing $6 \%$ brewer's yeast.

Table 2. Percentage composition of diets used for determination of the biological value of proteins by the growth method

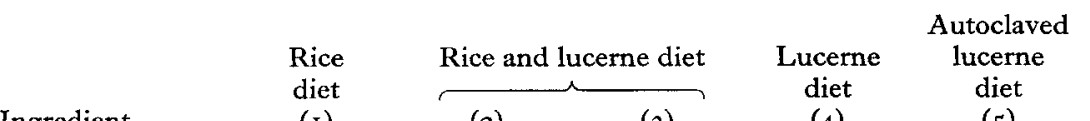

$\begin{array}{lccccc}\quad \text { Ingredient } & (\mathrm{I}) & (2) & (3) & (4) & (5) \\ \text { Rice (unpolished) } & 73 \cdot 0 & 54 \cdot 7 & 36 \cdot 5 & - & - \\ \text { Lucerne-leaf flour } & - & 4 \cdot 6 & 9 \cdot 2 & 18 \cdot 35 & - \\ \text { Autoclaved lucerne-leaf flour } & - & - & - & - & 18 \cdot 35 \\ \text { Coconut oil } & 10 \cdot 0 & 10 \cdot 0 & 10 \cdot 0 & 10 \cdot 0 & 10 \cdot 0 \\ \text { Cane sugar } & 10 \cdot 0 & 10 \cdot 0 & 10 \cdot 0 & 10 \cdot 0 & 10 \cdot 0 \\ \text { Salt mixture* } & 4 \cdot 0 & 4 \cdot 0 & 4 \cdot 0 & 4 \cdot 0 & 4 \cdot 0 \\ \text { Vitaminized starch } \dagger & 3 \cdot 0 & 3 \cdot 0 & 3 \cdot 0 & 3 \cdot 0 & 3 \cdot 0 \\ \text { Starch (maize) } & - & 13 \cdot 7 & 27 \cdot 3 & 54 \cdot 65 & 54 \cdot 65 \\ \text { Nitrogen } & 0 \cdot 978 & 0 \cdot 978 & 0 \cdot 994 & 1 \cdot 000 & 1 \cdot 067 \\ \text { Protein }(\mathrm{N} \times 6 \cdot 25) & 6 \cdot \mathrm{rI} & 6 \cdot 1 \mathrm{I} & 6 \cdot 2 \mathrm{I} & 6 \cdot 24 & 6 \cdot 42 \\ \text { Moisture } & 9 \cdot 0 & 9 \cdot 0 & 8 \cdot 75 & 8 \cdot 20 & 8 \cdot 0\end{array}$

Diet 2: rice protein:lucerne protein, $3: \mathbf{I}$.

Diet 3 : rice protein: lucerne protein, $1: 1$.

* Osborne \& Mendel (19r3).

$\dagger 3 \mathrm{~g}$ contained extract from $5 \mathrm{~g}$ brewer's yeast (ethyl alcohol added to $50 \%(\mathrm{v} / \mathrm{v})$ to an aqueous extract from yeast, precipitate filtered off and liquid dried), $0^{\circ} 15 \mathrm{mg}$ thiamine hydrochloride, $0^{\circ} 4 \mathrm{mg}$ riboflavin and $0.4 \mathrm{mg}$ nicotinic acid. Each rat received daily one drop of shark-liver oil containing I 500 i.u. vitamin $A$ and roo i.u. vitamin D per g. 


\section{RESULTS AND DISCUSSION}

The biological value of the proteins was calculated from the formula given by Chick, Hutchinson \& Jackson (1935). For calculating the endogenous urinary and faecal nitrogen for different periods, it was assumed that these values varied linearly between the first and the last periods (Mitchell, I924). The results obtained by the balancesheet method are presented in Table 3. The calculated biological value of the mixed proteins was compared with the experimentally obtained value by the pair-difference method. The value of the proteins in dehydrated lucerne was found to be 66 , slightly higher than those (62 and 60) reported by earlier workers (Nevens, I921; Smuts \& Malan, 1938). This difference may be due to the fact that these workers used the entire plant, including both stem and leaf, as the source of protein.

Table 3. Biological value for adult male rats of the proteins of lucerne leaf, of rice and of a mixture of the two

\begin{tabular}{|c|c|c|c|c|c|}
\hline \multirow{2}{*}{$\begin{array}{l}\text { Rat } \\
\text { no. }\end{array}$} & \multirow[b]{2}{*}{ Lucerne } & \multirow[b]{2}{*}{ Rice } & \multicolumn{3}{|c|}{ Rice and lucerne } \\
\hline & & & Observed & Expected $\uparrow$ & Observed-expected \\
\hline $\mathbf{I}$ & $65 \cdot 3$ & $92 \cdot 4$ & $90 \cdot 2$ & $8 \mathrm{I} \cdot 3$ & $8 \cdot 9$ \\
\hline 2 & $67^{\circ} \circ$ & $89 \cdot 2$ & $9 \mathrm{I} \cdot 0$ & $80 \cdot 2$ & 10.8 \\
\hline 3 & 61.0 & 9100 & $86 \cdot 5$ & $78 \cdot 9$ & $7 \cdot 6$ \\
\hline 4 & 65.9 & $9 \pi \cdot 3$ & $86^{\circ} 4$ & $8 \mathrm{I} \cdot \mathrm{I}$ & 53 \\
\hline 5 & $72 \cdot 2$ & 89.5 & $84 \cdot 8$ & $82 \cdot 5$ & $2 \cdot 3$ \\
\hline $\begin{array}{l}\text { Mean with its } \\
\text { standard error }\end{array}$ & $66 \cdot 3 \pm 1 \cdot 65$ & $90 \cdot 7 \pm 0.92$ & $87 \cdot 8 \pm \mathrm{I} \cdot 20$ & $80 \cdot 8 \pm 0.63$ & $\begin{array}{c}6 \cdot 98 \pm \mathrm{I} \cdot 47 \\
t=4 \cdot 76^{*}\end{array}$ \\
\hline
\end{tabular}

The biological value of the mixed proteins (lucerne protein: rice protein, 2:3) was found to be high (88) and approached that of rice. Table 3 shows that the experimentally obtained value for the mixed proteins was invariably higher than the value calculated on the assumption that no supplementary relationship exists between them. The increase in biological value, as indicated by the pair-difference method, was not large, but was significant even at the $1 \%$ level. Hence it can be concluded that a definite supplementary relationship exists between the proteins of rice and lucerne in meeting the maintenance requirements of adult rats.

The growth studies (Table 4) showed a more pronounced supplementary relationship between rice and lucerne proteins. The protein efficiency ratio of the mixtures $(2 \cdot 5 \mathrm{I})$ was considerably higher than the ratio of either source of protein given separately. If the theoretically expected values are compared with the values obtained in the experiments, it is found that the latter exceeded the former by 34 and $54 \%$. The difference in growth rate between the rats receiving the mixtures and those receiving rice alone was striking. Since the balance method did not reveal such marked supplementary relationships, it may be concluded that a combination of rice and lucerne proteins is more effective in fulfilling requirements for growth than requirements for maintenance. 
There was no difference in the protein efficiency ratios of the two diets containing mixed proteins (Table 4, diets 2 and 3 ). This finding shows that the addition of even a small amount of lucerne to rice will improve protein quality-a fact which may be of practical importance, since it would be easier to include small rather than large quantities of lucerne in the rice diets of poor people.

Table 4. Weight gain of weanling male rats on diets of lucerne, rice, or a mixture of the two, and protein efficiency ratio of the diets

(Figures are the means of six determinations)

\begin{tabular}{|c|c|c|c|c|c|c|c|c|}
\hline \multirow[b]{3}{*}{$\begin{array}{l}\text { Diet } \\
\text { no. }\end{array}$} & \multirow[b]{3}{*}{$\begin{array}{l}\text { Source of } \\
\text { protein }\end{array}$} & \multicolumn{2}{|c|}{ Body-weight } & \multirow{3}{*}{$\begin{array}{c}\text { Adjusted } \\
\text { 6-week } \\
\text { gain* } \\
\text { (g) }\end{array}$} & \multirow{3}{*}{$\begin{array}{l}\text { Total } \\
\text { food } \\
\text { intake } \\
(\mathrm{g})\end{array}$} & \multirow{3}{*}{$\begin{array}{l}\text { Total } \\
\text { protein } \\
\text { intake } \\
(\mathrm{g})\end{array}$} & \multirow{2}{*}{\multicolumn{2}{|c|}{ Protein efficiency ratio }} \\
\hline & & & Gain in & & & & & \\
\hline & & $\begin{array}{l}\text { Initial } \\
(\mathrm{g})\end{array}$ & $\begin{array}{l}6 \text { weeks } \\
\text { (g) }\end{array}$ & & & & $\begin{array}{l}\text { Mean with its } \\
\text { standard error }\end{array}$ & Expected $\uparrow$ \\
\hline I & Rice & $39 \cdot 5$ & $40 \cdot 7$ & $40 \cdot 7$ & $312 \cdot 1$ & $19 \cdot 1$ & $2 \cdot 13 \pm 0.05$ & - \\
\hline 2 & $\begin{array}{l}\text { Rice and } \\
\text { lucerne, } 3: 1\end{array}$ & $39 \cdot 2$ & $54^{\circ} \mathrm{I}$ & $47^{\circ} \mathrm{I}$ & $347 \cdot 9$ & $2 \mathrm{I} \cdot 3$ & $2.5 I \pm 0.08$ & $I \cdot 87$ \\
\hline 3 & $\begin{array}{l}\text { Rice and } \\
\text { lucerne, } I: I\end{array}$ & $39 \cdot 8$ & 60.0 & $45 \cdot 3$ & $38 I \cdot 6$ & 23.7 & $2 \cdot 51 \pm 0 \cdot 11$ & $I \cdot 6 I$ \\
\hline 4 & Lucerne & $39 * 3$ & $18 \cdot 2$ & $27 \cdot 6$ & $257^{\circ} 0$ & $16 \cdot 0$ & $1 \cdot 09 \pm 0.14$ & - \\
\hline 5 & $\begin{array}{l}\text { Lucerne, } \\
\text { autoclaved }\end{array}$ & $39 \cdot 2$ & I $1 \cdot 4$ & $23 \cdot 6$ & $236 \cdot 2$ & $15 \cdot 2$ & $0.75 \pm 0.08$ & - \\
\hline
\end{tabular}

A difference between protein efficiency ratios is significant at the $5 \%$ level if it exceeds \pm 0.29 .

* The means in the previous column have been adjusted to a protein intake of $19.04 \mathrm{~g}$ by a withingroup regression coefficient. A difference between adjusted growth means is significant at the $5 \%$ level if it exceeds $\pm 4.6 \mathrm{~g}$.

$\dagger$ If there were no supplementary relationship between the proteins.

The supplementary effect of lucerne is probably due to the correction of the lysine deficiency of rice proteins (Kik, I940). Lucerne proteins contain $50 \%$ more lysine than rice proteins (Block \& Mitchell, 1946) and a small addition of lucerne will make good the deficiency of rice proteins in this respect. It is, of course, also possible that combining rice and lucerne proteins improves the relative proportion of other amino acids, and contributes to the higher protein efficiency ratio of the mixed proteins as compared with that of rice alone. In this connexion it may be noted that the nitrogenbalance experiments were done with adult rats, which have a lower lysine requirement than growing animals.

The proteins of lucerne leaf have been reported (Haag, 1934) to possess a low protein efficiency ratio $(0.40$ and 0.69 when given at levels of $I \mathrm{I} \cdot 0$ and $\mathrm{II} \cdot 7 \%$ protein respectively). In my experiments, in which the protein level was $6 \%$, the ratio observed was higher $(1 \cdot 09)$. The growth of the rats was, however, poor.

Smuts \& Marais (1938) did not find any supplementary relationship between groundnut meal and lucerne meal (the latter presumably including both leaf and stem). The experiments of Haag (1934) appear to indicate that the proteins of lucerneleaf meal and wheat bran supplement each other.

Table 4 shows that even mild autoclaving will impair the quality of lucerne proteins.

Variations between the groups in total food intake and hence in protein intake were large. Since the protein efficiency ratio tends to rise with increasing protein intake, the results were analysed by the covariance method (Snedecor, 1946), gains in weight 
being adjusted for variations arising out of differences in protein intake. The results confirmed the conclusions reported above, but showed that the differences in protein ratio recorded were somewhat exaggerated by the large differences in dietary protein intake.

\section{SUMMARY}

I. The biological value of the proteins in lucerne-leaf powder and their effect in supplementing rice proteins have been studied by the Thomas-Mitchell balance-sheet method and the rat-growth method. Five male adult rats were used in the balance test and five groups of six male newly weaned rats in the growth test.

2. Lucerne-leaf proteins had a low nutritive value. The biological value and digestibility were found to be 66 and 74 respectively. The protein efficiency ratio was $I \cdot 0 r$.

3. Both the balance method and the growth method showed a definite supplementary relationship between lucerne proteins and rice proteins, the effect being more pronounced in the growth experiments.

4. Rice and lucerne proteins together gave a mixture with a biological value of 88 and a protein efficiency ratio of $2 \cdot 5$.

5. A small amount of lucerne significantly increased the protein efficiency ratio of rice from $2 \cdot I$ to $2 \cdot 5$. The addition of a larger proportion of lucerne did not lead to a further rise.

6. Mild autoclaving reduced the protein efficiency ratio of lucerne-leaf powder.

I thank Dr V. Subrahmanyan, Director, Central Food Technological Research Institute, Mysore, for valuable suggestions and Mr A. N. Sankaran, statistician, for covariance analysis of the data.

\section{REFERENCES}

Anandswamy, B. \& Date, W. B. (1956). Bull. cent. Food tech. Res. Inst. 5, 105. Aykroyd, W. R. \& Krishnan, B. G. (r937a). Indian F. med. Res. 24, 667. Aykroyd, W. R. \& Krishnan, B. G. (1937b). Indian F. med. Res. 24, ro93. Aykroyd, W. R. \& Krishnan, B. G. (1937c). Indian F. med. Res. 25, I. Block, R. J. \& Mitchell, H. H. (1946). Nutr. Abstr. Rev. 16, 249.

Brown, A. \& Tisdall, F. F. (1933). Brit. med. F. i, 55.

Chick, H., Hutchinson, C. D. \& Jackson, H. M. (1935). Biochem. F. 29, 1702.

Escudero, P. \& Landabure, P. B. (1943). Rev. Ass. argent. Diet. I, I 43 .

Haag, J. R. (1934). F. Nutr. 8, 235.

Heupke, W. \& Schöller, R. (1942). Chem. Zbl. rr, 27r r.

Heupke, W. \& Schöller, R. (r943). Pharm. Ind. ro, I6o.

Kik, M. C. (1940). Cereal Chem. 17, 473.

Levy, L. F. \& Fox, F. W. (1935). Biochem. F. 29, 884.

Marston, H. R., Quinlan-Watson, F. \& Dewey, D. F. (1943). F. Coun. sci. industr. Res. Aust. I6, I I 3. Mitchell, H. H. (x924). F. biol. Chem. 58, 873.

Nevens, W. B. (1921). F. Dairy Sci. 4, 552 .

Odendaal, W. A. (1954). Food Ind. S. Afr. 6, no. I1, p. 25.

Osborne, T. B. \& Mendel, L. B. (I913). F. biol. Chem. 15, 317.

Osborne, T. B., Mendel, L. B. \& Ferry, E. L. (1919). F. biol. Chem. 37, 223.

Smuts, D. B. \& Malan, A. I. (1938). Onderstepoort $\mathscr{F}$. vet. Sci. ro, 207.

Smuts, D. B. \& Marais, J. S. C. (1938). Onderstepoort $\mathcal{F}$. vet. Sci. II, I 5 I.

Snedecor, G. W. (1946). Statistical Methods, 4th ed., p. 318 . Iowa State College Press.

Subrahmanyan, V. \& Sur, B. K. (1949). Indian F. med. Res. 37, 3 I 9.

Sur, B. K. \& Subrahmanyan, V. (1954). Curr. Sci. 23, 188.

Swaminathan, M. (1937). Indian F. med. Res. 24, 767.

White, J. W., Weil, L., Naghski, J., Monica, E. S. D. \& William, J. J. (1948). Industr. Engng Chem. (Industr.) 40, 293. 